\begin{tabular}{|c|c|c|}
\hline Beitr. Ent. & Keltern & ISSN 0005-805X \\
\hline $\mathbf{5 9}(2009) 2$ & S. $311-317$ & 15.12 .2009 \\
\hline
\end{tabular}

\title{
Reproductive behaviour and larval development of Prionyx thomae (FABRICIUS) from Brazil
}

\section{(Hymenoptera: Sphecidae)}

With 6 figures and 1 table

SAndor Christiano Buys

\section{Summary}

The nesting behaviour and larval development of the solitary wasp Prionyx thomae (FABRICIUs) are described. Observations on male behaviour are also provided. The study is based on observations carried out in four places of the Rio de Janeiro State (southeastern Brazil). The following species of grasshoppers (Orthoptera: Acrididae) are reported as prey: Orphulella punctata (De GeER), Rhammatocerus pseudocyanipes Assis-Pujol, Abracris flavolineata (DE GEER) and Ronderosia bergi (STÅL).

\section{Zusammenfassung}

Nistverhalten und Larvalentwicklung der solitären Wespe Prionyx thomae (FABRICIUs) werden, ergänzt um Bemerkungen zum Verhalten der Männchen, beschrieben. Die Studie beruht auf Beobachtungen, die an vier Orten im Staat Rio de Janeiro (südöstliches Brasilien) angestellt wurden. Folgende Heuschreckenarten (Geradflügler: Acrididae) konnten als Beute identifiziert werden: Orphulella punctata (De Geer), Rhammatocerus pseudocyanipes Assis-Pujol, Abracris flavolineata (De GeER) und Ronderosia bergi (STÅL).

Key words

Wasp, nesting, biology, male behaviour, territoriality, larva

\section{Introduction}

Prionyx Vander Linden is a genus of solitary grasshopper-hunting wasps (BoHART \& MenKe 1976) with 59 species (PUlAwski 2008). There are behavioural studies on about 10 species of Prionyx (see Pulawski 2008), but only a few species were studied in detail (e.g. Evans 1958). Prionyx thomae (FAbricius), distributed from Argentina to the United States (Willink 1951, Evans 1958), seems to be the commonest species of the genus in South America. Several papers were published on its biology (e. g. Hartman 1905, Williams 1913, Rau \& Rau 1918, Bodkin 1918, Evans 1958, Grissell 1981), the respective observations been conducted mostly in Central America and southern United States. Several aspects of its behaviour, however, were not treated in previous papers and the observations by GrIsSELL (1981) suggest that the behaviour of $P$. thomae can be quite variable. Herein the nesting behaviour and larval development of $P$. thomae are described and observations on male behaviour are provided. 


\section{Material end methods}

Observations were conducted in the following localities in the State of Rio de Janeiro (southeastern Brazil): (1) Restinga de Barra de Maricá (RBM), city of Maricá $\left(22^{\circ} 55^{\prime} 10^{\prime \prime} \mathrm{S}\right.$ and $\left.42^{\circ} 49^{\prime} 07^{\prime \prime} \mathrm{W}\right)$; (2) Parque Municipal de Grumari (PMG), city of Rio de Janeiro (22 $54^{\prime} 10^{\prime \prime S}$ and $\left.43^{\circ} 12^{\prime} 27^{\prime \prime} \mathrm{W}\right)$; (3) Parque Nacional da Restinga de Jurubatiba (PNRJ), city of Macaé (22 $22^{\prime} 15^{\prime \prime} \mathrm{S}$ and $\left.41^{\circ} 47^{\prime} 13^{\prime \prime W}\right)$; (4) Reserva Biológica de Poço das Antas (RBPA), city of Silva Jardim (22³9'03"S and $\left.42^{\circ} 23^{\prime} 30^{\prime \prime} \mathrm{W}\right)$. RBM, PMG and PNRJ are covered with a peculiar savanna-like vegetation type, called restinga, which grows on costal plains in southeastern Brazil. RBPA is covered with Atlantic Tropical rain forest. Most of the observations were conducted in RBM, which was visited monthly from May 2000 to April 2001; the other three localities were sporadically visited from 2001 to 2003.

The complete nesting cycles of 12 females were observed (Tab. 1), but dozens of other females were observed in different phases of the nesting cycle. Larval development, from egg to mature larva, was observed in laboratory on two grasshoppers collected in RBM. The preys were kept in jars lined inside with slightly moistened absorbent paper to avoid the dissection of the egg or larva; faeces of the prey were daily removed to avoid fungus proliferation.

Voucher specimens of the wasps and their prey have been deposited in the Hymenoptera collection of the Museu Nacional - Universidade Federal do Rio de Janeiro.

\section{Results}

\section{Habitat and annual occurrence:}

In RBM nesting females were observed every month from May 2000 to April 2001, except August and December, indicating that they reproduced throughout the year in that locality. In RBM and PNRJ the nests were found in the margins of unpaved roads, in soil composed of sand mixed with clay, whereas in PMG the nests were in open areas in sandy soil. In RBPA the nests were found in the margins of an unpaved road that crosses a forested area in hardly compacted clay soil. All nests were located predominantly in exposed sites without litter or low vegetation.

\section{Preys and nest provisioning:}

The females hunted exclusively on adult grasshoppers (Orthoptera: Acrididae). In PNRJ, RBM and PMG, areas covered with restinga vegetation, they hunted on Orphulella punctata (DE GEER) and Rhammatocerus pseudocyanipes Assis-Pujol; in RBPA, a forested area, the females preyed on Abracris flavolineata (DE GEER) and Ronderosia bergi (STÅL).

\section{Storing the prey:}

The female hunts the prey before digging the nest and stores the paralyzed grasshopper in a hiding place on a tuft of low vegetation (Tab. 1). Subsequently, she makes an orientation flight around the prey-storing place and leaves in search for a nesting site.

\section{Nesting site selection:}

To select the nesting site, the female walks on the ground touching the soil with the antennae, and digs in several points making shallow burrows that are soon abandoned. Commonly, the female throws earth backward beneath the body with the forelegs into the abandoned burrows; but usually she spends only a few seconds in this activity and the burrows are rarely fulfilled. During the 
selection of the nesting site, sometimes the female returns to the storing place to check on the prey. One female from RBM spent 27 minutes in searching for the nesting site; she dug four short burrows before digging the definitive nest and checked the prey in the storing-place four times.

\section{Digging behaviour:}

The female performs the following behavioural sequence to dig the nest: (1) cuts the soil with the mandibles, (2) accumulates a lump of earth between the head and the forelegs, (3) walks backwards up to the nest entrance, and (4) throws the earth backward beneath the body with a flip of the head and forelegs. The thrown earth reaches a few millimetres beyond the wasp's body and remains accumulated in a small sector near the nest. Occasionally, the female scatters this mound of earth with her forelegs. In the early stage of the nest construction the female frequently interrupts the excavation and characteristically looks around; at this time she is easily frightened, and even a little disturbance near the nest causes her flying away. Thus, apparently she is vigilantly checking the nesting place.

\section{Nest structure:}

The nest is an oblique tunnel in the soil with a terminal cell, in which the prey is stored. Measurements of some nests are given in the Table 1. One nest from RBM was unusual in being constructed in a slope with the tunnel almost parallel to the ground surface.

Tab. 1: Quantitative parameters of the nesting behaviour of Prionyx thomae observed in four places from Rio de Janeiro State: Restinga de Barra de Maricá (RBM), Reserva Biológica de Poço das Antas (RBPA), Parque Nacional de Jurubatiba (PNJ) and Reserva Municipal de Grumari (RMG)

Nest structure: $\mathrm{OD}=$ opening diameter $(\mathrm{mm}), \mathrm{ML}=$ maximum length $(\mathrm{cm}), \mathrm{MD}=$ maximum depth $(\mathrm{cm})$; first prey storing-place: $\mathrm{DN} 1=$ distance from the nest $(\mathrm{m}) ; \mathrm{AA}=$ distance from the ground $(\mathrm{cm})$; second prey storing-place: $\mathrm{DN} 2=$ distance from the nest $(\mathrm{m})$; time spent in behavioural phases (minutes): $\mathrm{S}=$ nesting site selection; $\mathrm{D}=$ nest digging; $\mathrm{C}=$ nest closing; $\mathrm{T}=$ total time from the prey storing up to the finalization of the nest closing.

\begin{tabular}{|c|c|c|c|c|c|c|c|c|c|c|c|}
\hline Place & Female & OD & ML & MD & ND1 & AA & DN2 & $S$ & D & $\mathrm{C}$ & $\mathrm{T}$ \\
\hline \multirow{6}{*}{ RBM } & I & - & - & 3.5 & 6 & - & 0.8 & 15 & 14 & 5 & 47 \\
\hline & II & - & - & 4 & 6.6 & 3 & - & 15 & 15 & 9 & 39 \\
\hline & III & 11 & - & 3.5 & - & - & 0.8 & - & - & - & - \\
\hline & IV & - & - & 4.1 & 1.2 & - & 0.2 & - & - & - & - \\
\hline & $\mathrm{V}$ & $6-7$ & - & 4.2 & - & 2 & - & - & - & - & - \\
\hline & VI & 6.5 & 5.3 & - & - & 5 & - & - & - & - & 12 \\
\hline \multirow{2}{*}{ RBPA } & VII & - & 4.5 & 2.5 & - & - & absent & - & - & - & 60 \\
\hline & VIII & 10 & - & 3 & - & - & - & - & - & - & - \\
\hline \multirow{2}{*}{ PNRJ } & IX & - & - & 3.5 & 1.4 & 1.5 & absent & - & 17 & - & - \\
\hline & $\mathrm{X}$ & - & - & 2.5 & - & - & - & - & - & - & - \\
\hline \multirow{2}{*}{ PMG } & XI & - & - & 4.2 & - & - & - & - & - & - & - \\
\hline & XII & - & 5 & 3.2 & 3.5 & - & 1.2 & - & - & - & - \\
\hline
\end{tabular}

\section{Prey transport and a second prey-storing place:}

Soon after the completion of the nest, the female takes the prey from the storing place. She grasps the prey's antennae with the mandibles, straddles its body, and walks on the ground toward the nest. The females from RBM and PMG deposited the prey in a second storing place, also on a 
small tuft of grasses, made an orientation flight, and went checking the nest; then they entered the burrow for a few seconds, and back to search for the prey. The females observed in RBPA and PNRJ transported the prey to the nest in a similar way, however, they did not use a second storing place.

\section{Placement of the prey inside the nest:}

In order to place the prey into the nest, the female performs the following sequence: (1) puts the prey in front of the nest entrance, (2) enters the burrow walking forward, (3) turns around inside the nest (4) partially exits the nest walking forward, (5) grasps the prey's antennae with her mandibles, and (6) pulls it into the nest walking backward.

\section{Nest closure:}

After pulling the prey inside the nest, the female oviposits, and starts to close the nest. She picks up lumps of soil from the nest surroundings with her mandibles and puts them into the nest. Inside the burrow she emits a buzzing sound that probably is a resulted of her compacting or modelling the soil. Usually the nest is almost completely fulfilled with lumps of soil and the opening becomes unrecognizable from the nearby ground. One female grasped a stone with the mandibles and pressed on the nest closure to compact the earth.

\section{Adult feeding and notes on male behaviour:}

Several females were found feeding on flowers of an unidentified species of Boreria (Rubiaceae) in RBM. This herbaceous plant is commonly found gregariously growing in sunny open places. The females visit sequentially flowers of Boreria following more or less a straight line. In the same sites males of $P$. thomae were observed hovering over the plants and sometimes landing on flowers, but they were not observed feeding on them. The male behaviour was studied in detail in RBPA, where a male was uninterruptedly followed for two hours in the margin of an unpaved road in a sunny place with several small herbaceous plants. This male slowly flied in a repetitive trajectory within about $25 \mathrm{~m}$. Most of the time he flied about 20 to $30 \mathrm{~cm}$ above the ground, and never changed the flying direction before completing the entire trajectory. He frequently landed on branches or leaves of herbaceous plants, but he did not feed on them. A conspecific male entered in the area and landed on some flowers; he flied more quickly than the resident male and in a random trajectory. For three times the two males encountered each other and behaved stereotypically flying face to face upward in a spiral course, then flying away in different directions without physical contact. After the last encounter the intruder male departed.

\section{Development and behaviour of the larva:}

The observations on the two larvae conducted in the laboratory were very similar, so the development of only one of them, which was collected in May 2000, is described below. Evans \& LiN (1956) provided a morphological description of the last instar larva of $P$. thomae.

May, 25: The prey bearing the wasp's egg was collected from the nest at the early afternoon. Even partially paralyzed, the prey excreted faeces and was able to slightly move its mouthparts, antennae, and legs. Sometimes the prey strongly moved the hindlegs, as it does when jumping. The wasp's egg was intense yellow and U-shaped. An extremity of the egg was attached to a membranous portion of the prey thorax at the base of a hindcoxa (Fig. 1).

May, 27: The egg hatched in the morning and the larva partially penetrated into the prey's body at the point where the egg was attached (Fig. 2). The newly-hatched larva was yellow, but less intensely coloured than the egg; at night the larva became light brown in colour. 

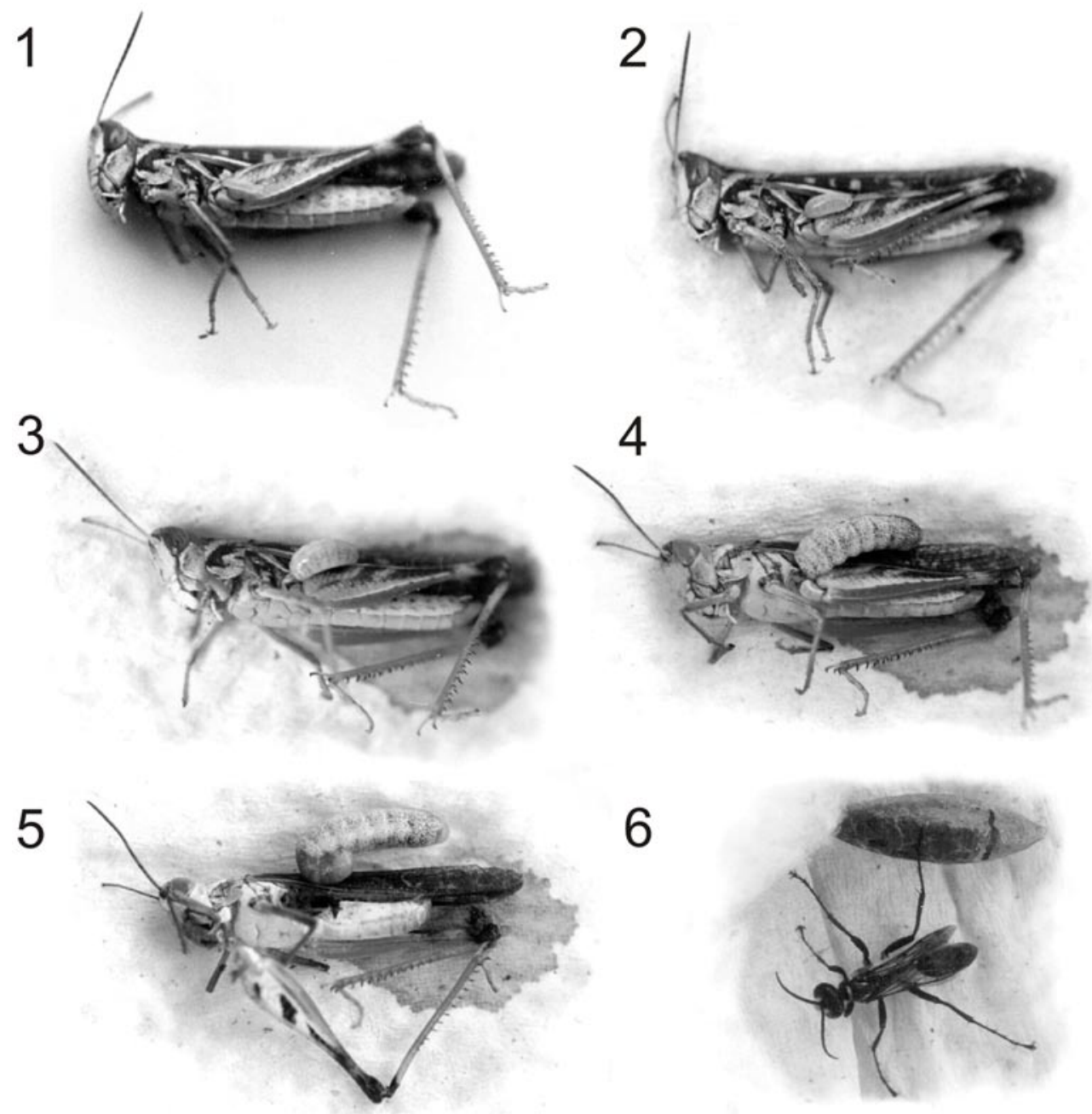

Figs 1-6: Development of a male Prionyx thomae, consuming a specimen of the grasshopper Rhammatocerus pseudocyanipes. (1) Prey bearing the wasp's egg; (2) first day of larval development; (3) second day of larval development; (4) third day of larval development, the prey is death; (5) fourth day of larval development, full-grown larva; (6) adult male and its cocoon.

May, 28: The larva remained in the same position, without apparent external movements, but grew in body size. The prey expelled a dark liquid, which stained the paper that lined the rearing jar around the prey abdomen (Fig. 3); she scarcely moved and still in the morning stopped to respond to mechanical stimulus, indicating that she was death. During the day, the larva gradually became greyish white in colour.

May, 29: The first external movements of the larva were observed; it slightly contracted the body when the rearing jar was moved; however, she remained in the same position (Fig. 4). The larva's body was yellow in the anal segment and reddish brown on the rest of the body, but the red colouration was due to internal structures; the integument was translucent. 
May, 30: The larva exited from the prey body and remained besides her (Fig. 5). The exoskeleton of the prey was rather preserved; only one hindleg had been dismembered from her body (Fig. 5). Two portions was sharply distinguished in the larva body: (1) the portion that remains immerse in the prey body, which was narrower, cylindrical and able of moving in all directions, formed by the head, thorax and the two first abdominal segments; (2) and the portion that remains out from the prey body, which was dorsiventrally flattened, with limited movements, and formed by the abdominal segments III-X. White granules of uric acid were visible under the integument of the larva. These granules were abundant in all the body, except in the anal segment. After some hours, the larva started to move and stretched the anterior portion of the body; apparently she was trying to touch the walls of the tube with the mouthparts. Then, she was transferred to a glass tube and soon she started to spin her cocoon. Firstly, she spun silken threads on the bottom and around the tube and, before effectively starting to spin the cocoon, she excreted a red substance on the cotton used to block the tube. The cocoon was attached to the tuft of cotton in this point. At night the external capsule of the cocoon was ready.

May, 31: The larva spun the internal capsule of the cocoon. Both the capsules were fusiform in shape and brown in coloration, but the internal one was darker. The cocoon was shorter than the larval length; thus she remains with the thorax bended over the abdomen inside the cocoon.

June, 24: An adult male emerged from the cocoon (Fig. 6).

July, 19: The adult male died in captivity.

\section{Discussion}

The motor patterns of $P$. thomae dealing with the nest digging and prey manipulation are similar to those of other species of Prionyx (see Rau \& Rau 1918, Evans 1958, Buys 2006). However, two behavioural patterns herein described in females of $P$. thomae are remarkable in having been rarely observed in the other species of the genus: (1) the placement of the prey in a second storing-place and (2) the vigilant behaviour in an early stage of the nest excavation. The placement of the prey in a second storing-place could be interpreted as defence against parasitoids, especially those that search for open nests to larviposit (see Evans \& West-Eberhard 1970). Females of Prionyx do not temporarily close their nests, which remain open all the time, and the moment the females are transporting the prey to the nest usually is the longer time the nest remains open and alone, therefore this seems to be the more vulnerable moment to be attacked by parasitoid flies. When the female interrupt the prey transport trip to check the nest, she reduces the time the nest remains open and unguarded; thus diminishing its vulnerability to parasitoids. Vigilant behaviour in the early stage of nest excavation probably is also related to defence against parasitoids or predators. Remarkably, these two nest defensive behaviours were observed in Prionyx fervens (Linnaeus) by Buys (2006), species that co-occurs with $P$. thomae in southeastern Brazil. Possibly these two types of behaviour are widespread among the species of Prionyx, but have been overlooked by other observers who studied this genus, but another possibility is that both of these species have been exposed to similar evolutionary pressure in southeastern Brazil and convergently developed these defensive behaviours.

Observations on behaviour of male sphecid are rare and very scattered in the literature, but apparently male territoriality was not previously observed in species of the genus Prionyx. Some notes on territoriality exist on males of the related genus Sphex; KuRCZEwski (1998) detailed studied this subject on Sphex pensylvanicus Linnaeus, but he found a kind of territoriality different from that observed in $P$. thomae. On the other hand, Hager \& Kurczewski (1985) found that males of Ammophila harti (FERNALD) flied over fixed areas, very similarly to those of $P$. thomae, but unlike the 
latter species, they do not defend these areas. The observed males of $P$. thomae clearly defend fixed areas from conspecific males; thus their behaviour can be interpreted as territorial. The territories are maintained in places that females use for foraging. Although copulation of $P$. thomae has not been observed, it seems likely that it occurs on the vegetation in the areas the males defend. Male territorial behaviour as that herein observed apparently was not previously reported in Sphecidae.

\section{Acknowledgements}

I thank Cinara Andrade for assisting in the field work and Cristiane Assis Pujol for identifying the grasshoppers.

\section{References}

Bodkin, G. E. 1918: Notes on some British Guiana Hymenoptera (exclusive of the Formicidae). - The Transaction of the Entomological Society of London 1917: 297-321, pls XXI-XXIII.

Bohart, R. M. \& Menke, A. S. 1976: Sphecidae wasps of the world - a generic revision. - Pp. ix + 695 . - Berkeley: University of California Press.

Buys, S. C. 2006: Nesting behaviour and larval biology of Prionyx fervens (Linnaeus) (Hymenoptera: Sphecidae) from Brazil. - Revista Brasileira de Zoologia 23: 311-313.

Evans, H. E. 1958: Studies on the nesting behaviour of the digger wasps of the tribe Sphecini. Part I. Genus Priononyx Dahlbom. - Annals of the Entomological Society of America 51: 177-186.

Evans, H. E. \& Lin, C. S. 1956: Studies on the larvae of digger wasps (Hymenoptera, Sphecidae) Part I: Sphecinae. - Transactions of the American Entomological Society 81: 131-153, pls. I-VIII.

Evans, H. E. \& West-Eberhard, M. J. 1970: The wasps. Pp. vi + 265. - Ann Arbor: The University of Michigan Press.

Grissell, E. E. 1981: Nesting behaviour of Prionyx 'thomae' (FAbricius) (Hymenoptera: Sphecidae). Journal of the Kansas Entomological Society 54: 16-21.

Hager, B. J. \& Kurczewski, F. E. 1985: Reproductive behaviour of male Ammophila harti (Fernald) (Hymenoptera: Sphecidae). - Proceedings of the Entomological Society of Washington 87: 597-605.

Hartman, C. G. 1905: Observations on the habits of some solitary wasps of Texas. - Bulletin of the University of Texas 65: 1-72+4 pls.

KunCzewski, F. E. 1998: Territoriality and mating behavior of Sphex pensylvanicus L. (Hymenoptera: Sphecidae). - Journal of Hymenoptera research 7 (1): 74-83.

Pulawski, W. J. 2008: Catalog of Sphecidae sensu lato. Available from: <http: // www. calacademy. org /research / entomology / Entomology _ Resources / Hymenoptera / sphecidae/ Genera _ and _ species _ PDF / introduction. htm.>. Accessed on 05.05.2008.

RaU, P. \& RaU, N. 1918: Wasp studies afield. - New York, Dover Publications [fac-simile from the original book published by the Princeton University Press]: 372 pp.

Williams, F. X. 1914: Notes on the habits of some solitary wasps that occur in Kansas, with the description of a new species. - The Kansas University Science Bulletin 18: 223-230, pl. XXXIII.

WiLlink, A. 1951: Las especies argentinas y chilenas de "Chloriontini" (Hymenoptera, Sphecidae). - Acta Zoologica Lilloana 11: 53-225.

Author's adress:

Sandor Christiano Buys

Departamento de Entomologia

Museu Nacional, Universidade Federal do Rio de Janeiro

Quinta da Boa Vista, São Cristóváo, 20.940-040, Rio de Janeiro, RJ, Brazil

E-mail: sbuys@biologia.ufrj.br

\section{Subject editor:}

Prof. Dr. J. OehlKe 